\title{
Scaffolding Protein
}

National Cancer Institute

\section{Source}

National Cancer Institute. Scaffolding Protein. NCI Thesaurus. Code C38764.

Scaffolding Proteins participate in many cellular functions by serving as a supportive base that spatially or temporally organizes, juxtaposes, regulates, and/or promotes the function of other cellular elements (usually proteins). ( $\mathrm{NCl}$ ) 